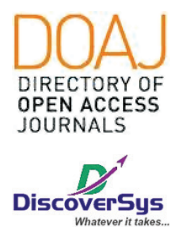

Published by DiscoverSys

\section{Perbedaan kadar protein C, protein S dan antitrombin III pada pasien dengan Sindrom Koroner Akut (SKA) di RSUP H. Adam Malik, Medan, Indonesia}

Maisyaroh Tiurma Anggraini Saragih, ${ }^{1 *}$ Adi Koesoema Aman, ${ }^{1}$ Nizam Akbar ${ }^{2}$
'Departemen Patologi Klinik, Fakultas Kedokteran Universitas Sumatera Utara, RSUP H. Adam Malik, Medan, Indonesia 2Departemen Kardiologi dan Kedokteran Vaskular, Fakultas Kedokteran Universitas Sumatera Utara, RSUP H. Adam Malik, Medan, Indonesia

*Korespondensi:

Maisyaroh Tiurma Anggraini Saragih; Departemen Patologi Klinik, Fakultas Kedokteran Universitas Sumatera Utara, RSUP H. Adam Malik, Medan, Indonesia;

mtasaragih@gmail.com

\title{
ABSTRACT
}

Background: Acute coronary syndrome (ACS) is a life-threatening condition where coronary artery blockage results from thrombosis and leads to ischemia. Individuals with partial deficiency of protein C, protein S or antithrombin III have been found to play a role in increasing the risk of thrombosis. This study aims to determine differences in levels of protein C, protein S and antithrombin III in patients with ACS. Methods: A cross-sectional study was carried out among 60 patients who were treated at H. Adam Malik General Hospital Medan and had fulfilled the inclusion and exclusion criteria through consecutive sampling techniques. Protein C, protein $S$ and antithrombin III were examined with Coatron A4. Bivariate analysis was used to determine differences in the mean levels of protein C, protein S, and antithrombin
III in ACS compared with healthy controls. Data were analyzed using SPSS version 17 for Windows.

Results: There were a significant difference in $S$ protein levels between the STEMI, NSTEMI, and control groups $(P<0.05)$. S protein levels in the STEMI group were significantly lower compared to NSTEMI and control $(P<0.05)$. However, there were no significant differences in levels of protein ( and AT-III between the STEMI, NSTEMI and control groups $(\mathrm{P}>0.05)$.

Conclusion: There were no significant differences in ATIII and protein C levels between the STEMI, NSTEMI, and ATIII groups. However, in the $S$ protein parameter, the $S$ protein level was significantly different between STEMI, NSTEMI and the control group.

Keywords: Protein C, protein S, antithrombin III, ACS, STEMI, NSTEMI

Cite This Article: Saragih, M.T.A., Aman, A.K., Akbar, N. 2019. Perbedaan kadar protein C, protein S dan antitrombin III pada pasien dengan Sindrom Koroner Akut (SKA) di RSUP H. Adam Malik, Medan, Indonesia. Intisari Sains Medis 10(3): 688-692. D0I: 10.15562/ism.v10i3.500

ABSTRAK

Latar Belakang: Sindrom koroner akut (SKA) adalah merupakan kondisi yang mengancam hidup dimana terjadi penyumbatan arteri koroner akibat trombosis dan berujung pada iskemia. Individu dengan defisiensi parsial protein $C$, protein $S$ atau Antitrombin III telah diketahui turut berperan pada peningkatan risiko trombosis. Penelitian ini bertujuan untuk mengetahui perbedaan kadar protein C, protein $S$ dan antitrombin III pada pasien dengan SKA

Metode: Studi potong lintang dilakukan terhadap 60 pasien yang berobat atau dirawat di RSUP H. Adam Malik Medan dan telah memenuhi kriteria inklusi dan eksklusi melalui teknik konsekutif. Protein C, protein $S$ dan antitrombin III diperiksa dengan Coatron A4. Analisis bivariat digunakan untuk mengetahui perbedaan rerata kadar protein C, protein
S dan antitrombin III pada SKA dibandingkan dengan kontrol sehat. Data dianalis menggunakan SPSS versi 17 untuk Windows.

Hasil: Terdapat perbedaan kadar protein $S$ yang bermakna antara kelompok STEMI, NSTEMI dan control $(P<0,05)$. Kadar protein $S$ pada kelompok STEMI secara bermakna lebih rendah dibandingkan NSTEMI dan control $(P<0,05)$. Namun, tidak terdapat perbedaan kadar protein ( dan AT-III yang bermakna antara kelompok STEMI, NSTEMI dan control $(P>0,05)$.

Kesimpulan: Tidak terdapat perbedaan ATIII dan protein C yang bermakna antara kelompok STEMI, NSTEMI dan ATIII. Namun pada parameter protein S, kada protein S berbea signifikan antara STEMI, NSTEMI dan kelompok kontrol.

Kata Kunci: Protein C, protein S, antitrombin III, SKA, STEMI, NSTEMI

Cite Pasal Ini: Saragih, M.T.A., Aman, A.K., Akbar, N. 2019. Perbedaan kadar protein C, protein S dan antitrombin III pada pasien dengan Sindrom Koroner Akut (SKA) di RSUP H. Adam Malik, Medan, Indonesia. Intisari Sains Medis 10(3): 688-692. D0I: 10.15562/ism.v10i3.500

\section{PENDAHULUAN}

Sindrom koroner akut (SKA) adalah istilah yang dipakai untuk menyatakan tanda dan gejala klinis iskemia miokard maupun infark miokard. Iskemia maupun infark miokard tersebut meliputi angina pektoris tidak stabil (unstable angina), infark miokard akut elevasi segmen ST/ST-segment 
elevation myocardial infarction (STEMI), dan infark miokard akut tanpa elevasi segmen ST/ non ST-segment elevation myocardial infarction (NSTEMI). Keadaan ini sangat mengancam jiwa ${ }^{1}$

Frekuensi SKA sangat mengejutkan, lebih dari 1,4 juta orang dirawat di rumah sakit di Amerika Serikat setiap tahun dengan kondisi ini. Sekitar $38 \%$ pasien yang mengalami SKA akan meninggal sebagai hasil akhirnya. Walaupun demikian, terlepas dari statistic yang menakutkan ini, kematian terkait SKA sebenarnya mengalami penurunan dengan berkembangnya terapi dan preventif yang berkembang decade terakhir. ${ }^{2}$

Sebagian besar infark miokard akut adalah manifestasi akut dari plak ateroma pembuluh darah koroner yang koyak atau pecah. Hal ini berkaitan dengan perubahan komposisi plak dan penipisan tudung fibrus yang menutupi plak tersebut. Kejadian ini akan diikuti oleh proses agregasi trombosit dan aktivasi jalur koagulasi. Terbentuklah trombus yang kaya trombosit (white thrombus). ${ }^{3}$

Trombus ini akan menyumbat liang pembuluh darah koroner, baik secara total maupun parsial; atau menjadi mikroemboli yang menyumbat pembuluh koroner yang lebih distal. Selain itu terjadi pelepasan zat vasoaktif yang menyebabkan vasokonstriksi sehingga memperberat gangguan aliran darah koroner. Berkurangnya aliran darah koroner menyebabkan iskemia miokardium. Pasokan oksigen yang berhenti selama kurang-lebih 20 menit menyebabkan miokardium mengalami nekrosis (infark miokard). ${ }^{3}$

Pada keadaan normal, antitrombin III (AT III), protein $\mathrm{C}$ dan protein $\mathrm{S}$ sebagai kofaktor protein aktif, merupakan antikoagulan alami (pengontrol hemostasis) yang berperan menyeimbangkan aktivitas prokoagulan (keseimbangan kompleks antitrombin-trombin), untuk mencegah terjadinya thrombosis. Dalam keadaan tak seimbang, antikoagulan alami dan prokoagulan dapat menyebabkan terjadinya thrombosis. ${ }^{4}$

Defisiensi Protein C dan AT III dapat memicu SKA dengan koefisien determinan masing-masing sebesar 9,06\% dan 13,25\%. Aktivitas protein C rendah menunjukkan risiko yang lebih besar untuk SKA daripada aktivitas tingkat rendah AT III. Kekurangan protein $S$ adalah faktor penguat pada defisiensi AT III untuk SKA. Cut off point aktivitas AT III tanpa defisiensi protein $S$ yang diharapkan dapat menyumbang penyakit pembuluh tunggal adalah $45 \%$ dan $9,5 \%$ terhadap penyakit pembuluh darah tiga kali lipat. ${ }^{4}$

Seperti yang diketahui bahwa heparin digunakan sebagai antikoagulan pada tatalaksana pasien dengan SKA. Heparin meningkatkan aktivitas ATIII dan menetralisir factor koagulasi protease serin yang diaktifkan. Pasien dengan defisiensi ATIII yang memerlukan terapi antikoagulan dengan heparin memerlukan dosis heparin yang lebih tinggi. ATIII mengikat thrombin dan kemudian membentuk kompleks thrombin-anti thrombin atau kompleks TAT. Ini adalah jalur alami utama antikoagulan. Pengikatan thrombin ke AT ini sangat meningkat dengan adanya heparin. ${ }^{4}$

Berkaitan dengan pemaparan di atas maka penelitian ini bertujuan untuk mengetahui perbedaan kadar protein C, protein $S$ dan antitrombin III pada pasien dengan Sindrom Koroner Akut (SKA) di RSUP H. Adam Malik, Medan, Indonesia

\section{METODE}

Studi analitik potong lintang (Cross-sectional) dilakukan terhadap 60 pasien SKA untuk mengetahui perbedaan rerata kadar protein $\mathrm{C}$, protein $S$, dan antitrombin III serum. Penelitian ini dilakukan pada bulan Agustus sampai Oktober 2018 di unit perinatologi RSUP H. Adam Malik Medan.

Populasi penelitian adalah pasien dewasa yang datang berobat ke Departemen Kardiologi di RSUP Haji Adam Malik Medan yang memeriksakan darah lengkap di Departemen Patologi Klinik pada bulan Agustus 2018 - Oktober 2018. Subjek penelitian adalah pasien dewasa penderita SKA yang memenuhi kriteria inklusi dan eksklusi. Pengambilan sampel dilakukan secara konsekutif terhadap semua populasi. Jumlah sampel minimal sesuai perkiraan jumlah sampel atau sampai batas waktu pengumpulan sampel yang ditentukan. Adapun kriteria inklusi yang dipergunakan pada penelitian ini adalah: 1) pasien dewasa yang telah didiagnosis sebagai SKA di Departemen Kardiologi RSUP H. Adam Malik Medan dan 2) bersedia untuk terlibat dalam penelitian melalui informed consent. Sedangkan kriteria eksklusi pada penelitian ini adalah: 1) Diabetes mellitus; 2) Infeksi akut; dan 3) baru mengkonsumsi aspirin atau obat-obatan yang mempengaruhi hemostasis

Bahan yang digunakan dalam penelitian ini adalah darah dengan antikoagulan sitrat disentrifugasi dengan kecepatan $3500 \mathrm{rpm}$ selama 15 menit dan diperiksa dengan Coatron A4. Data yang diperoleh kemudian dianalisis dengan piranti lunak SPSS versi 17 untuk Windows. Analisis multivariat dilakukan terhadap data pada penelitian ini. Untuk data demografis dilakukan analisis multivariat sehingga didapatkan distribusi karakteristik sampel. Analisis bivariat dan multivariate digunakan untuk mengetahui perbedaan rerata kadar protein $\mathrm{C}$, protein $\mathrm{S}$ dan antitrombin III pada pasien SKA baik yang STEMI ataupun NSTEMI dibandingkan dengan kelompok 
kontrol. Uji statistik yang digunakan adalah uji $\mathrm{T}$ independen apabila data berdistribusi normal atau uji Mann Whitney apabila data tidak berdistribusi normal.

\section{HASIL}

Penelitian ini melibatkan 40 orang pasien Sindrom Koroner Akut (SKA) yang dibedakan atas 20 pasien SKA dengan STEMI dan 20 orang pasien SKA dengan NSTEMI sesuai dengan kriteria inklusi dan eksklusi serta 20 orang kontrol normal. Terhadap sampel penelitian dilakukan pemeriksaan Kadar Protein C, Protein S, dan Antitrombin III. Data yang dikumpulkan disajikan dalam bentuk Tabel 1 .

Penelitian ini diikuti oleh 60 yang terdiri dari 20 orang pada masing-masing kelompo yang telah memenuhi kriteria inklusi dan eksklusi. Pada Kelompok STEMI terdapat 18 orang laki-laki dan 2 orang perempuan, kelompok NSTEMI terdapat 14 orang laki-laki dan 6 orang perempuan, sedangkan pada kelompok kontrol terdapat 13 orang lakilaki dan 7 orang perempuan. Berdasarkan usia, nilai median kelompok STEMI adalah $50(32-70)$ tahun, rerata kelompok NSTEMI adalah 57,6 + 7,56 tahun, dan median kelompok NSTEMI adalah 57,5 $(48$ - 79) tahun (Tabel 1).

Hasil penelitian ini menunjukkan bahwa terdapat perbedaan kadar protein $\mathrm{S}$ yang bermakna antara kelompok STEMI, NSTEMI dan control $(\mathrm{P}<0,001)$. Kadar protein $S$ pada kelompok STEMI juga menunjukkan hasil lebih rendah secara bermakna dibandingkan NSTEMI dan control $(\mathrm{P}<0,001)$. Akan tetapi tidak terdapat perbedaan bermakna antara kadar protein C dan AT-III antara kelompok STEMI, NSTEMI dan control $(\mathrm{P}>0,05)$ (Tabel 2).

Terdapat perbedaan kadar Protein $S$ yang bermakna antara kelompok STEMI dan NSTEMI $(\mathrm{P}<0,001)$. Kadar protein $\mathrm{S}$ secara bermakna lebih rendah pada STEMI. Hasil penelitian ini juga menunjukkan bahwa terdapat perbedaan kadar Protein S yang bermakna antara kelompok NSTEMI dan control $(\mathrm{P}<0,001)$. Kadar protein $S$ diketahui lebih rendah secara bermakna pada NSTEMI. Selain itu hasil yang diperoleh menunjukkan terdapat perbedaan kadar Protein S yang bermakna antara kelompok NSTEMI dan control $(\mathrm{P}<0,001)$ (Tabel 2).

\section{PEMBAHASAN}

Sindroma Koroner Akut (SKA) diketahui bersifat multifactorial. Hal ini dikarenakan banyak faktor yang terlibat di dalamnya baik dikarenakan tekanan darah tinggi, post exercise hypotension, maupun akibat sindrom metabolik yang mengacu pada ketidak seimbangan profil lipid terutama pada pasien dengan DM-2.5 ${ }^{5-7}$ Berkaitan dengan hal tersebut maka penelitian ini dilakukan untuk mengetahui parameter biomarker tertentu yang dapat dijadikan alternatif acuan pada pasien dengan SKA.

Penelitian ini dilakukan sejak bulan Juni sampai September 2018. Subjek penelitian terbagi ke dalam beberapa karakteristik diantaranya jenis kelamin dan umur. Pada penelitian ini dikumpulkan 40 sampel pasien yang terbagi atas 20 pasien dengan Sindrom Koroner Akut (SKA) tipe STEMI dan 20 pasien dengan SKA tipe NSTEMI dengan jumlah

Tabel 1 Perbandingan data demografis pada responden penelitian

\begin{tabular}{|c|c|c|c|c|c|c|}
\hline \multirow[b]{2}{*}{ Karakteristik } & \multicolumn{2}{|c|}{ SKA STEMI $(n=20)$} & \multicolumn{2}{|c|}{ SKA NSTEMI $(n=20)$} & \multicolumn{2}{|c|}{ KONTROL $(n=20)$} \\
\hline & $\begin{array}{l}\text { n/ median } \\
\text { (min-max) }\end{array}$ & $\begin{array}{c}\% / \text { mean } \\
\text { rank }\end{array}$ & $\begin{array}{c}\mathrm{n} / \text { rerata } \pm \\
\text { SB }\end{array}$ & $\begin{array}{c}\% / \text { mean } \\
\text { rank }\end{array}$ & $\begin{array}{l}\mathrm{n} / \text { median } \\
\text { (min-max) }\end{array}$ & $\begin{array}{c}\% / \text { mean } \\
\text { rank }\end{array}$ \\
\hline \multicolumn{7}{|c|}{ Jenis Kelamin (n) } \\
\hline Laki-laki & 18 & 90 & 14 & 70 & 13 & 65 \\
\hline Perempuan & 2 & 10 & 6 & 30 & 7 & 35 \\
\hline Usia (Tahun) & $50(32-70)$ & 22,1 & $57,5 \pm 7,56$ & 34,7 & $57,5(48-79)$ & 34,7 \\
\hline
\end{tabular}

Tabel 2 Perbandingan parameter Protein C, Protein S dan AT-III antara pasien STEMI, NSTEMI dan Kontrol

\begin{tabular}{lcccc}
\hline Parameter & $\begin{array}{c}\text { STEMI } \\
\mathbf{n = 2 0}\end{array}$ & $\begin{array}{c}\text { NSTEMI } \\
\mathbf{n = 2 0}\end{array}$ & $\begin{array}{c}\text { Kontrol } \\
\mathbf{n = 2 0}\end{array}$ & $\mathbf{P}$ \\
\hline Protein C (\%) & $40(19,2-61,3)$ & $40,05(16,2-180)$ & $44,45(3,6-60,5)$ & 0,424 \\
Protein S (\%) & $36,4(14,6-180)$ & $53,65(5,6-180)$ & $180(37,1-180)$ & $<0,001^{\text {abcd }}$ \\
AT-III (\%) & $33,2(22,5-111,5)$ & $34,95(25,0-110,9)$ & $31,7(26,1-111,7)$ & 0,726 \\
\hline
\end{tabular}

${ }^{\mathrm{a}} \mathrm{p}<0,05$ dengan uji Kruscall Wallis; ${ }^{\mathrm{b}} \mathrm{p}<0,05$ dengan uji Mann-Whitney U antara STEMI dan NSTEMI $(0.03) ;{ }^{c} \mathrm{p}<0,05$ dengan uji Mann-Whitney U antara NSTEMI dan Kontrol (0.015); ${ }^{\mathrm{d}} \mathrm{p}<0,05$ dengan uji Mann-Whitney U antara STEMI dan Kontrol ( $\left.<0.001\right)$ 
total pasien laki-laki sebanyak 32 orang $(80 \%)$ dan perempuan 8 orang (20\%). Jumlah pasien lakilaki lebih banyak daripada perempuan ini sejalan dengan hasil penelitian Derhasching et al., pada tahun 2002, McCann et al., pada tahun 2008, dan Tumade et al., pada tahun 2016 dimana pada penelitian mereka prevalensi Sindrom Korener Akut pada laki-laki lebih banyak dari pada perempuan. Hal ini juga diduga disebabkan efek protektif dari hormone esterogen yang dimiliki oleh perempuan. ${ }^{8}$ Hal ini juga disebabkan dominasi populasi perokok oleh laki-laki, dimana merokok juga penyebab terjadinya disfungsi endotel yang nantinya dapat menyebabkan suatu atherosclerosis. ${ }^{8-12}$

Pada kelompok SKA, umur dibagi menjadi dua kelompok yaitu $<57$ tahun dan $>58$ tahun. Pasien SKA yang berumur $<57$ tahun sebanyak 20 orang $(50 \%)$ dan pasien SKA yang berumur $>58$ tahun juga sebanyak 20 orang (50\%). Hal ini menunjukkan bahwa terdapat peningkatan jumlah pasien SKA pada umur $<57$ tahun dimana selama ini diketahui bahwa pasien SKA lebih besar pada umur $>58$ tahun. Hal ini didukung oleh penelitian Ting et al (2007) yang mendapatkan bahwa terjadi peningkatan jumlah pasien di atas 50 tahun yang di rawat di ICCU karena sindrom koroner akut. Penelitian lain yang dilakukan Nababan pada tahun 2008 di RSU Pirngadi Medan juga menunjukkan hasil yang sama yaitu penyakit jantung koroner terdapat lebih banyak pada kelompok usia $>40$ tahun. ${ }^{13,14}$

Pada kelompok pasien SKA terdapat tiga pasien $(7,5 \%)$ yang berusia dewasa muda yaitu 38 tahun dan 32 tahun. Penelitian Tumade et al di Manado juga mendapatkan pasien SKA usia 31-40 tahun sebanyak 2 kasus $(1,6 \%)$ pada penelitiannya. Hal ini sesuai dengan data yang dihimpun oleh American Heart Association (2017) bahwa terdapat peningkatan prevalensi SKA berdasarkan usia baik pada kelompok usia di bawah 39 tahun maupun di atas 58 tahun. $^{10,15}$

Sindrom Koroner Akut (SKA) adalah salah satu penyebab utama kematian dan mortalitas di negara maju dan berkembang. Banyak Beberapa masalah genetika dan lingkungan dapat menjadi faktor penyebabnya. Ada banyak faktor risiko hematologi yang terlibat pada kasus-kasus SKA di antaranya adalah defisiensi antitrombin III, defisiensi protein $\mathrm{C}$ dan defisiensi protein S. Secara umum, faktor-faktor ini mengakibatkan trombosis, sehingga memiliki efek negatif pada jantung.

Dari penelitian ini ditemukan median kadar protein C pada kelompok pasien STEMI, NSTEMI dan Kontrol berbeda namun tidak signifikan dengan nilai $\mathrm{P}$ sebesar 0,424 . Hal ini sesuai dengan penelitian Vaziri, et al pada tahun 1991 yang menunjukkan bahwa terdapat perbedaan kadar protein C pada kelompok kontrol dan SKA namun tidak bermakna. Callas et.al pada tahun 1998 dalam penelitiannya juga menyebutkan bahwa tidak ada perbedaan kadar protein $\mathrm{C}$ yang signifikan antara kelompok kontrol dan SKA. Hal ini juga sejalan dengan penelitian yang dilakukan oleh Akyurek et al bahwa kadar protein $\mathrm{C}$ pada pasien dan kontrol tidak memiliki perbedaan yang bermakna. ${ }^{16-18}$

Median Kadar protein S pada kelompok pasien adalah kelompok STEMI 36,4\% (14,6 - 180), kelompok NSTEMI 53,65 (5,6 - 180) dan pada kontrol adalah $180(37,1$ - 180) dengan hasil uji statistik didapatkan perbedaan bermakna dengan nilai $\mathrm{p}<0,05$. Hal ini sesuai dengan penelitian pendahulu oleh Callas et al yang menunjukkan perbedaan yang signifikan antara kadar protein $S$ pada pasien SKA dibandingkan dengan kontrol normal. ${ }^{17}$

Median kadar Antitrombin III (AT-III)) pada kelompok pasien STEMI adalah $33.2(22,5-111,5)$ $\%$, kelompok pasien NSTEMI adalah 34.95\% $(25,0$ - 110,9) dan pada kontrol adalah $31,7(26,1$ - 111,7$) \%$, dengan hasil uji statistik didapatkan perbedaan tidak bermakna dengan nilai $\mathrm{p}=0,726$. Hal ini sesuai dengan penelitian Vaziri, et al yang menunjukkan bahwa tidak terdapat perbedaan kadar AT-III yang bermakna antara kelompok pasien dan kelompok kontrol. Hal yang sama juga didapati pada penelitan yang dilakukan oleh Akyurek, et al pada tahun 2014 dan Callas et al pada tahun 1998 bahwa tidak ada perbedaan kadar AT-III yang signifikan antara kelompok pasien SKA dan kelompok kontrol. ${ }^{16-18}$

Hipotesis penelitian adalah bahwa kadar protein C, protein $\mathrm{S}$ dan ATIII akan lebih rendah pada individu yang mengalami SKA dari pada kelompok kontrol. Namun pada penelitian ini ditemukan bahwa nilai Protein C dan ATIII tidak berbeda signifikan dengan kelompok kontrol.

Hasil protein C dan ATIII yang didapatkan dalam penelitian ini konsisten dengan laporan dari ARIC yang menunjukkan bahwa protein $C$ dan ATIII tidak lebih rendah pada individu yang memiliki insiden SKA dibandingkan kelompok yang tidak. Secara teori, dapat dijelaskan bahwa tidak menurunnya kadar protein C dan ATIII ini adalah karena terjadinya proses umpan balik dimana keduanya meningkat akibat dari peningkatan produk degradasi fibrin. Produk degradasi fibrin diketahui menyebabkan peningkatan sistesis fibrinogen in vitro melalui mekanisme mediasi IL-6. ${ }^{17,18}$

Sebagaimana diketahui bahwa protein $\mathrm{S}$ mempengaruhi aktivitas protein $\mathrm{C}$, kadar protein $\mathrm{C}$ yang tidak menurun tidak berarti tingkat antikoagulan juga dalam keadaan normal. Aktivitas antikoagulan protein $\mathrm{C}$ dibatasi oleh kadar protein $\mathrm{S}$ yang rendah yang ditemukan pada pasien SKA. ${ }^{17,18}$ Kadar 
protein S bebas yang rendah mungkin dapat dijelaskan dengan adanya peningkatan ikatan antara protein S dengan protein C4BP (Complement Factor C4B Binding Protein) yang diketahui meningkat selama respon inflamasi. Defisiensi protein $S$ yang diperoleh diketahui terjadi pada peradangan atau kondisi lain yang ditandai dengan peningkatan $\mathrm{C} 4 \mathrm{BP}$ dan berhubungan dengan peningkatan risiko trombotik. ${ }^{17,18}$

\section{SIMPULAN}

Hasil penelitian ini menunjukkan bahwa terdapat perbedaan kadar protein S yang bermakna antara kelompok SKA baik yang STEMI maupun NSTEMI dibandingkan dengan kelompok control. Akan tetapi, tidak terdapat perbedaan kadar protein $\mathrm{C}$ dan ATIII yang bermakna antara kelompok SKA baik yang STEMI maupun NSTEMI dibandingkan dengan kelompok control.

\section{ETIKA PENELITIAN}

Penelitian ini telah mendapat persetujuan etik dari Komisi Etik, Fakultas Kedokteran Universitas Sumatera Utara, RSUP H. Adam Malik, Medan, Indonesia sebelum penelitian berjalan.

\section{KONFLIK KEPENTINGAN}

Tidak terdapat konflik kepentingan dalam penulisan laporan penelitian ini.

\section{PENDANAAN}

Penulis bertanggung jawab dalam pendanaan penelitian ini secara mandiri tanpa melibatkan pihak sponsor, grant, atau sumber pendanaan lainnya

\section{KONTRIBUSI PENULIS}

Seluruh penulis berkontribusi sama dalam penulisan laporan penelitian ini dari penyusunan kerangka penelitian, pengambilan data, analisis data, hingga laporan hasil penelitian.

\section{DAFTAR PUSTAKA}

1. Overbaugh KJ. Acute Coronary Syndrome. Am J Nurs. 2009;109(5):42-52

2. Rhee JW, Sabatine MS, Lilly LS. Acute Coronary Syndromes. In Lilly LS: Pathophysiology of Heart Disease: Acollaborative Project of Medical Students and Faculty. 5th ed. Baltimore: LW\&W. 2011:161-165
3. PERKI. Pedoman Tatalaksana Hipertensi pada Penyakit Kardiovaskular. Edisi ke-3. Perhimpunan Dokter Spesialis Kardiovaskular Indonesia, Jakarta. 2015

4. Ismail D, Harun S, Alwi I, Tambunan KL, Effendy S. Anti-thrombin III, Protein C and Protein S Deficiency in acute coronary syndrome. Medical Journal of Indonesia. 2002;11(2):87-92.

5. Artha IMJ, Bhargah A, Dharmawan NK, Pande UW, Triyana KA, Mahariski PA, et al. High level of individual lipid profile and lipid ratio as a predictive marker of poor glycemic control in type-2 diabetes mellitus. Vasc Health Risk Manag. 2019; 15: 149-157

6. Pertiwi GAR, Aryawangsa AAN, Prabawa IPY, Manuaba IBAP, Bhargah A, Ratni NWS, Budiana IPG. Factors associated with visit-to-visit variability of blood pressure in hypertensive patients at a Primary Health Care Service, Tabanan, Bali, Indonesia. Family Medicine and Community Health. 2018;6(1):191-199

7. Bhargah A, Muliarta M, Prabawa IPY, Manuaba IBAP, Bhargah V. Post-Exercise Hypotension Phenomenon in Elderly after Aerobic Exercise. Journal of Global Pharma Technology. 2018; 10(6):323-327

8. Derhaschnig U, Laggner A, Roogla M, Kapiotis S, Marsik C, et al. Evaluation of Coagulation Markers for early Diagnosis of Acute Coronary Syndromes in the Emergency Room. Clin Chem. 2002;48(11):1924-30.

9. McCann CJ, Glover BM, Menown IB, Moore MJ, McEneny J, Owen CG, et al. 2008. Novel biomarkers in early diagnosis of acute myocardial infarction compared with cardiac troponin T. Eur Heart J. 2008;29(23):2843-50.

10. Tumade B, Jim EL, Joseph VFF. Prevalensi Sindrom Koroner Akut di RSUP Prof. Dr. R. D. Kandou Manado periode 1 Januari 2014 - 31 Desember 2014. Journal e-Clinic. 2016;4(1):223-230

11. Rafieian-Kopaei M, Setorki M, Doudi M, Baradaran A, Nasri H. Atherosclerosis: Process, Indicators, Risk Factors and New Hopes. Int J Prev Med. 2014;5(8):927-946

12. Sumartono W, Sirait AM, Holy M, Thabrany H. Smoking and Socio-Demographic Determinant of Cardiovascular Diseases among Males 45+ Years in Indonesia. Int J Environ Res Public Health. 2011;8(2):528-539.

13. Ting P, Chua TS, Wong A, Sim LL, Tan VW, Koh TH. Trend in mortality from acute myocardial infarction in coronary care unit. Ann Acad Med Singapore. 2007;36(12):974-9.

14. Nababan D. 2008. Hubungan Faktor Risiko dan Karakteristik Penderita dengan Kejadian Penyakit Jantung Koroner di RSU Dr. Pirngadi Medan Tahun 2008. [Tesis] Medan, Universitas Sumatera Utara. 2008

15. Benjamin EJ, Virani SS, Callaway CW, Chamberlain AM, Chang AR, Cheng S, et al. Heart Disease and Stroke Statistics-2018 Update: A Report From the American Heart Association. Circulation. 2018;137(12):e67-e492.

16. Vaziri ND, Kennedy SC, Kennedy D. Coagulation, fibrinolytic, and inhibitory proteins in acute myocardial infarcion and angina pectoris. Am J Med. 1994;96(6):571.

17. Callas PW, Tracy RP, Bovill EG, Cannon C, Thompson B, Mann KG. The Association of Anticoagulant Protein Concentrations with Acute Myocardial Infarction in the Thrombolysis in Myocardial Infarction Phase II (TIMI II) Trial. J Thromb Thrombolysis. 1998;5(1):53-60.

18. Akruyek O, Akbal E, Gunes F. Increase in the risk of ST elevation myocardial infarction is associated with homocysteine level. Arch Med Res. 2014;45(6):501-6.

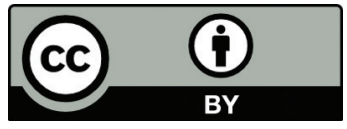

This work is licensed under a Creative Commons Attribution 